\title{
Peptides with 6-Aminohexanoic Acid: Synthesis and Evaluation as Plasmin Inhibitors
}

\author{
Maciej Purwin ${ }^{1}$ - Agnieszka Markowska ${ }^{1}$ Irena Bruzgo ${ }^{1}$ - Tomasz Rusak ${ }^{2}$. \\ Arkadiusz Surażyński $^{3} \cdot$ Urszula Jaworowska $^{1} \cdot$ Krystyna Midura-Nowaczek $^{1}$
}

Accepted: 9 September 2016/Published online: 19 September 2016

(C) The Author(s) 2016. This article is published with open access at Springerlink.com

\begin{abstract}
Fifteen new peptide derivatives of $\varepsilon$-aminocaproic acid (EACA) containing the known fragment -AlaPhe-Lys- with an affinity for plasmin were synthesised in the present study. The synthesis was carried out a solid phase. The following compounds were synthesised: $\mathrm{H}-$ Phe-Lys-EACA-X, H-D-Ala-Phe-Lys-EACA-X, HAla-Phe-Lys-EACA-X, H-D-Ala-Phe-EACA-X and $\mathrm{H}-$ Ala-Phe-EACA-X, where $\mathrm{X}=\mathrm{OH}, \mathrm{NH}_{2}$ and $\mathrm{NH}-$ $\left(\mathrm{CH}_{2}\right)_{5}-\mathrm{NH}_{2}$. All peptides, except for those containing the sequence $\mathrm{H}-\mathrm{Ala}-\mathrm{Phe}-\mathrm{EACA}-\mathrm{X}$, displayed higher inhibitory activity against plasmin than EACA. The most active and selective inhibitor of plasmin was the compound $\mathrm{H}-\mathrm{D}-$ Ala-Phe-Lys-EACA- $\mathrm{NH}_{2}$ which inhibited the amidolytic activity of plasmin $\left(\mathrm{IC}_{50}=0.02 \mathrm{mM}\right)$, with the antifibrinolytic activity weaker than EACA. The resulting peptides did not affect the viability of fibroblast cells, colon cancer cell line DLD-1, breast MCF-7 and MDA-MB-231 cell lines.
\end{abstract}

Keywords 6-Aminohexanoic acid P Plasmin inhibitors . Antifibrinolytics

Agnieszka Markowska

agnieszka.markowska@umb.edu.pl

1 Department of Organic Chemistry, Medical University of Bialystok, Mickiewicza 2A Str, 15-222 Białystok, Poland

2 Department of Physical Chemistry, Medical University of Bialystok, Mickiewicza 2A Str, 15-222 Białystok, Poland

3 Department of Medicinal Chemistry, Medical University of Bialystok, Mickiewicza 2A Str, 15-222 Białystok, Poland

\section{Introduction}

Plasmin is a serine protease which is involved in many physiological processes such as wound healing, tissue repair and migration in addition to its main role in fibrin cleavage. Plasmin inhibition is crucial in preventing plasmin over-activity, i.e. in blood coagulation disorders or during surgeries. Plasmin inhibitors have also been tested for other disease states including angiogenesis, cell proliferation, metastasis and embryo implantation.

Plasmin (PL) is distributed in the form of zymogen called plasminogen (PLG) Activation of PLG to PL is a result of a single cleavage of the scissile bond between $\mathrm{Arg}^{561}$ and $\mathrm{Val}^{562}$ in plasminogen (Robbins et al. 1967). PLG is produced as a protein which consists of 810 amino acids. During secretion a short 19 amino acid peptide is cleaved to produce a mature zymogen which consists of 791 amino acids. PLG is a single chain protein whose activation results in a two-chain disulfide-linked plasmin which is a serine protease with specificity similar to trypsin cleaving after Lys and Arg. The amino-terminal heavy chain of PL consists of five kringle domains, each containing 80 amino acid residues. The $\mathrm{C}$-terminal light chain of plasmin is a typical serine protease (SP) which contains the catalytic triad composed of $\mathrm{His}^{603}, \mathrm{Asp}^{646}$ and $\mathrm{Ser}^{741}$.

Both plasmin and PLG exist in two forms which differ by sequences at the $N$-terminus (Fig. 1).

Glu-plasmin(ogen) (Glu-PL(G)) consists of glutamic acid at the $\mathrm{N}$-terminus and possesses tight conformation (Cockell et al. 1998) while Lys-plasmin(ogen) (Lys-PL(G)) with lysine at the $N$-terminus has a much more relaxed structure (Castellino and Ploplis 2005). PLG is activated by tissue PLG activator (tPA) and, to a lesser degree, by urokinase PLG activator (UPA) or a complex of bacterial metabolites from Streptococcus haemolyticus and 
Glu-PLG

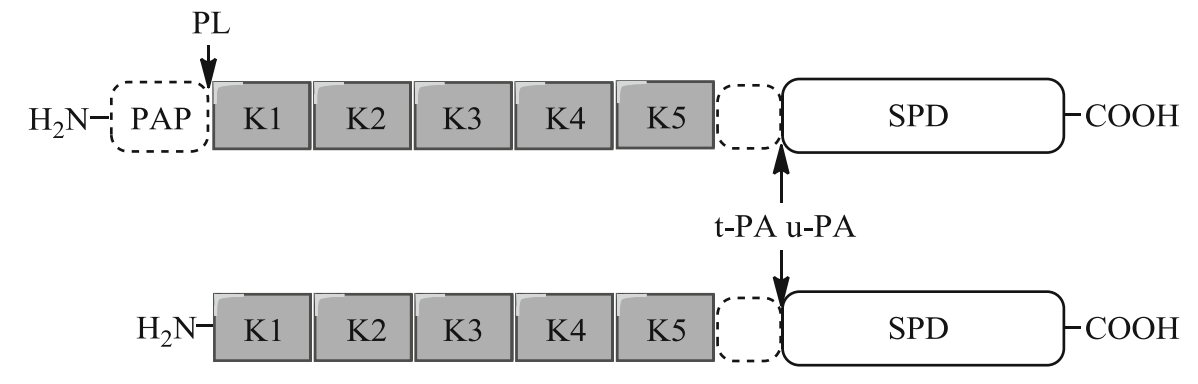

Lys-PLG

Glu-PL

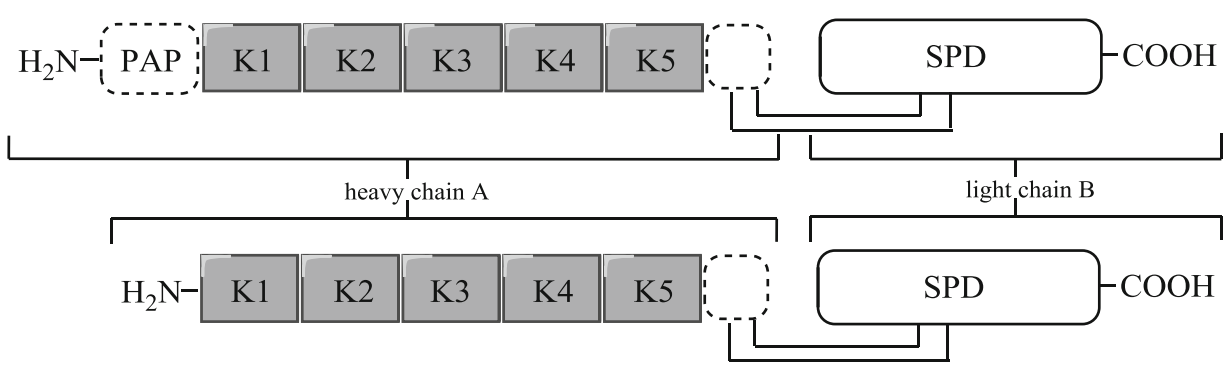

Fig. 1 Forms of plasminogen and plasmin: one-chain Glu- and Lys-plasminogen and two-chain disulfide-linked Glu- and Lys-plasmin

Staphylococcus aureus. The main role of t-PA is the dissolution of blood clots in vessels while u-PA is involved in mediating cell-related proteolysis. A number of studies have confirmed the role played by u-PA in embryogenesis (Berg and Menino 1992), embryo implantation and fertilisation (Sappino et al. 1989; Huarte et al. 1993), angiogenesis (Pepper et al. 1996), cancer and metastasis (Carroll and Binder 1999).

Plasminogen activation by tPA requires the presence of fibrin to which PLG and TPA bind via LBS located in the kringle domain of PLG (Lerch et al. 1980). Once formed, plasmin action is confined to the fibrin surface due to the kringle-mediated binding of plasmin to fibrin (Lucas et al. 1983). Plasmin proteolytically cleaves the fibrin clot and, as a result, restores blood flow to the affected tissues. The most important function of plasmin is intravascular thrombolysis although the proteolytic activity in normal and pathological conditions causes cell migration, inflammation and tissue remodelling (Carmeliet and Collen 1995). The evidence also suggests a less defined function of plasmin in a number of physiological and pathological processes relating to hormones, immunology, fertility, inflammation, bone formation, extracellular matrix degradation, cell migration and tissue remodelling. The effects of plasmin are specific, require the active catalytic centre and can be antagonised by lysine analogues, implying binding of the plasmin molecule to the cell membrane through its lysine binding sites.

Inhibition of the fibrinolytic system is mediated by plasminogen activator inhibitors, mainly by PLG activator inhibitor PAI-1, and by plasmin inhibitors, mainly $\alpha_{2}$-antiplasmin, which exist in high concentrations in plasma and rapidly inactivate any free plasmin that could appear outside a blood clot (Moroi and Aoki 1976). Fibrinolysis plays a crucial role in blood clot degradation, cell invasion, but also embryogenesis, embryo implantation, ovulation and brain barrier function (Collen and Lijnen 1991; Vassalli et al. 1991) (Fig. 2).

At present, analogues of lysine, including $\varepsilon$-aminocaproic acid (EACA), are commonly used as fibrinolysis inhibitors. EACA is a synthetic derivative of the amino acid lysine which produces reversible blockade of lysine binding sites (LBS) of kringle 1 and 4 on PLG molecules, thus preventing PLG binding to fibrin and reducing the conversion of PLG to plasmin which is responsible for the degradation of blood clots (Kahar et al. 2009; Bhavanis et al. 2013). EACA and tranexamic acid (TXA) exert their effect by inhibiting the protein-protein interaction between PLG and fibrin. They work by reversible prevent the protein-protein interaction via the blockade of LBS in the kringle domain (Hochschwender and Laursen 1981). EACA and TXA are widely and effectively used as adjuvants to decrease surgical field bleeding, reduce blood loss and subsequent need for blood transfusion in oral, orthopedic, spinal, cardiac surgery, liver transplantation and prostate surgery (Choi et al. 2009; Ortmann et al. 2013).

Activation of PLG to plasmin occurs in tissues where the proteolytic cleavage of biological barriers is needed i.e. wound healing, inflammation, inflammatory diseases including atherosclerosis and arthritis, ovulation and 


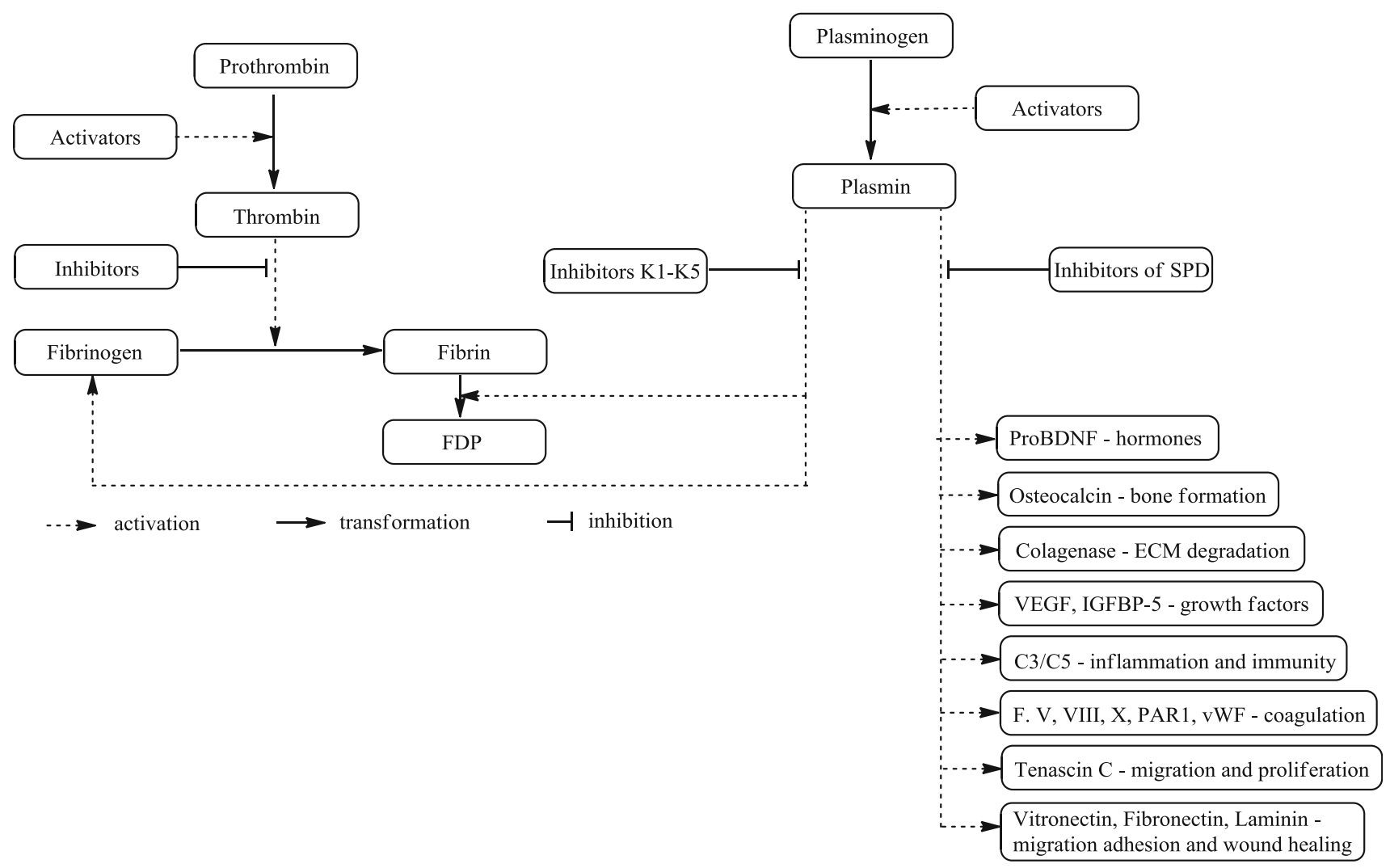

Fig. 2 Scheme of blood coagulation and fibrinolysis with a wide role of plasmin

trophoblast implantation, angiogenesis, nerve regeneration, and cell migration and proliferation during cancer. Active plasmin is formed close to the surface of tumor cells from PLG bound to cells. PLG is activated by the urokinase-type PLG activator which is produced by cancer or stroma cells. In physiological conditions, PL and UPA are inactivated by protease inhibitors such as $\alpha_{2}$-AP and PAI-1 present in the blood. Both uPA and plasmin degrade most of ECM components directly or through the activation of matrix metalloproteases (MMPs) (Kucharewicz et al. 2003; Kwaan and McMahon 2009). Plasmin is also responsible for the proteolytic activation of growth factors, including hepatocyte growth factor (Shanmukhappa et al. 2009), fibroblast growth factor (George et al. 2001) and transforming growth factor (Maeda et al. 2009).

Plasmin inhibitors are mostly classified as serine protease inhibitors. They bind targets through a highly conserved loop and form a reversible binding complex. A large number of compounds have been synthesised (Al-Horani and Desai 2014) but no drugs acting as short peptidyl plasmin inhibitors have been registered to date. The compounds did not meet drug registration requirements despite their increased activity. Consequently, the research for novel plasmin(ogen) binding inhibitors involves mimetics of lysine with modified functional groups (Fuji et al. 1972;
Okada et al. 1988) or small peptides consisting of EACA (Westlund et al. 1982; Muramatu and Fuji 1971). Further research led to the synthesis of specific compounds such as H-D-Val-Leu-Lys- $\mathrm{NHC}_{7} \mathrm{H}_{15}$ (Fareed et al. 1981) which showed only the antifibrinolytic activities of plasmin, but sometimes slight activation was observed (Nagamatsu et al. 1963). The optimal specificity for plasmin inhibitors seems to be Phe-Lys (Bajusz et al. 1981). This cleavage sequence has been identified in many natural and synthetic substrates (Backes et al. 2000). Derivatives of short peptides with C-terminal lysine carboxyl groups transformed into aldehyde (Friberger et al. 1982), chloro- and fluoromethyl ketone (Angliker et al. 1988; Ganu and Shaw 1987) or p-nitroanilide (Collen et al. 1980) are active directed inhibitors or synthetic substrates of plasmin.

During our investigation we combined EACA with Lys (Midura-Nowaczek et al. 2003), S-Bzl-Cys (MiduraNowaczek et al. 1994) or Nle (Midura-Nowaczek et al. 1996). These analogs showed variable antifibrinolytic activity relative to EACA (Bruzgo et al. 2006). The most selective inhibitor of the amidolytic activity of plasmin was Boc-EACA-Lys-EACA-NH ${ }_{2}$. Only the dipeptides BocLys(Z)-EACA-NH $\mathrm{NH}_{2}$ and Boc-Lys $\left(\mathrm{NH}_{2}\right)-\mathrm{EACA}-\mathrm{NH}_{2}$ appeared to be weak antifibrinolytics (Purwin et al. 2009). 
The tripeptide H-D-Ala-Phe-Lys is known as a trigger in some antitumor prodrugs activable by plasmin De Groot et al. $(1999,2000,2002)$. In our previous work we presented some antifibrinolytics such as heptyl amides and esters of tripeptides: Ala-Phe-Lys- $\mathrm{NHC}_{7} \mathrm{H}_{15}$ (MiduraNowaczek et al. 1996, 2006). Similar compounds with this sequences were the acid and amides of (D or L)-Ala-PheLys-OH( $\mathrm{NH}_{2}$ ) (Markowska et al. 2007). L-amino acid in the $\mathrm{P} 3$ position of tripeptides and their amides result in more effective inhibition than D-enantiomer. This result is in agreement with our previous research findings on the same tripeptide methyl ketones (Markowska et al. 2006). According to the literature, tripeptide synthetic substrates with D-configuration in P3 have better affinity for plasmin (Friberger et al. 1982).

Therefore, a new structure based on the tripeptidespacer -Ala-PheLys- and EACA was designed and proposed as new serine protease plasmin inhibitors and/or antifibrinolytics. There are no high specificity and low-dose drugs in current clinical use which act as inhibitors of the active site of plasmin and kringle structures simultaneously. There are only two registered antifibrinolytic drugs which inhibit LBS in the kringle structures of plasmin: EACA and tranexamic acid. Aprotinin is the sole inhibitor of the active centre of plasmin in clinical use and is derived from bovine pancreas (single-chain 58 amino acids polypeptide). In view of the considerable overexpression of plasmin in many pathological states a search for biologically active compounds which inhibit the activity of this enzyme appears important.

Fifteen substituted peptides with the general formula: X-Phe-Lys-EACA-Y and X-Phe-EACA-Y where $\mathrm{X}=\mathrm{H}, \mathrm{H}-\mathrm{D}-\mathrm{Ala}$, $\mathrm{H}-\mathrm{Ala}$ and $\mathrm{Y}=\mathrm{OH}, \mathrm{NH}_{2}, \mathrm{NH}-\left(\mathrm{CH}_{2}\right)_{5}-$ $\mathrm{NH}_{2}$ were synthesised using a solid phase and their effects on fibrinolytic and amidolytic activity were examined. The primary sequence of the peptides was -Ala-Phe-LysEACA - which was modified in order to establish structureactivity relationships. Their influence on other enzymes such as thrombin, tPA, uPA, kallikrein and trypsin were also tested. The compounds were tested in the cytotoxic test against breast cancer cell lines MCF-7 and MDA-MB231 and against colon cancer cell lines DLD.

\section{Experimental}

\section{Reagents}

Rink amide resin, chloranil, acetaldehyde, HOBt $=1$-hydroxybenzotriazole and TNBS $=2,4,6$-trinitrobenzenesulfonic acid (1\% solution in DMF) were purchased from Fluka (Schnelldorf, Germany). 2-Chlorotrityl chloride resin, 1,5-diaminopentanetrityl resin, Fmoc-EACA-OH
$($ Fmoc $=9$-fluorenylmethyloxycarbonyl, $\quad$ EACA $=6$ aminohexanoic acid), TFA = trifluoroacetic acid, DIPEA $=$ diisopropylethylamine, piperidine, $\mathrm{TBTU}=$ tetrafluoroborate salt of the $O$-(benzotriazol-1-yl)- $N, N, N^{\prime}, N^{\prime}$ tetramethyluronium tetrafluoroborate, NMP = 1-methyl-2pyrrolidon, Fmoc-Ala-OH, Fmoc-D-Ala-OH, FmocLys(Boc)-OH (Boc = benzyloxycarbonyl), Fmoc-Phe$\mathrm{OH}$ were obtained from Iris Biotech $\mathrm{GmbH}$ (Marktrewitz, Germany). $\mathrm{DCM}=$ dichloromethane, $\mathrm{DMF}=$ dimethylformamide and methanol were the products of Chempur (Piekary Slaskie, Poland). DCM was used without further purification. DMF was distillated over ninhydrin and stored under molecular sieves 4A. HPLC solvent acetonitrile was purchased from Merck (Darmstadt, Germany). Urokinase, trypsin, kallikrein and Bzl-L-Arg- $p$ NAHCl (Bzl = benzyl) were purchased from Sigma (Schnelldorf, Germany). Plasmin, S-2444 (pyro-Glu-Gly-Arg-pNAHCl), S-2238 (H-D-Phe-Pip-Arg-pNA), S-2251 (H-D-Val-Leu-Lys$p \mathrm{NA}$ ), S-2266 (H-D-Val-Leu-Arg- $p \mathrm{NA} 2 \mathrm{HCl}$ and S-2288 (H-D-Ile-Pro-Arg-pNA) were obtained from Chromogenix (Milano, Italy). Thrombin and phosphate buffered saline (PBS) were purchased from Lubelska Wytwórnia Szczepionek (Lublin, Poland). t-PA was obtained from Boehringer Ingelheim GmbH (Ingelheim, Germany).

\section{Peptide Synthesis}

The peptides shown in Table 1 were synthesized manually using the standard Fmoc-based strategy (Chan and White 2000). Fmoc deprotection steps were performed with $20 \%$ $(\mathrm{v} / \mathrm{v})$ piperidine in DMF/NMP (1:1) for 3 and $8 \mathrm{~min}$. separately. The peptide bonds with Fmoc amino acids were carried through urea coupling reagent TBTU in DMF/ NMP/DCM (1:1:1) of amino acid/TBTU/HOBt/resin using a molar ratio 3:3:3:1. The reactions were monitored with the Steward chloranil test (Vojkovski 1995) (chlorotrityl and Rink amide resins) and with the TNBS test (1,5-diaminopentanetrityl resin) (Hancock and Battersby 1976). The cleavage from the resin was carried out with TFA/ water (95/5). After $3 \mathrm{~h}$ stirring, the resin was filtered and washed with TFA. The combined filtrates were concentrated under reduced pressure. The crude peptide was washed with cold diethyl ether, filtered, dissolved in water and lyophilized. The Waters system (Waters Corporation, USA) was used for analytical and semipreparatory HPLC (Phenomenex C18, Jupiter 90A, 4 micron, $250 \times 4 \mathrm{~mm}$; Phenomenex C18, Jupiter 300A, 5 micron, $250 \times 10 \mathrm{~mm}$; solvents: A, $0.1 \%$ aqueous TFA; B, $0.1 \%$ TFA in acetonitrile, gradient $1-99 \% \mathrm{~B}$ in $\mathrm{A}$ in $30 \mathrm{~min}$, flow rate $1 \mathrm{ml} /$ min, monitored at $220 \mathrm{~nm}$ ). The major peak fraction was pooled and lyophilized. The molecular weight determination was performed by mass spectrometry using a Bruker 
Table 1 Physico-chemical parameters of synthesized compounds

\begin{tabular}{|c|c|c|c|c|c|}
\hline No & Compound & Yield $(\%)$ & Retention time (min) & MW & $\overline{(\mathrm{M}+\mathrm{H})^{+}}$ \\
\hline 1 & H-Phe-Lys-EACA-OH & 57 & 18.6 & 406.5 & 407.6 \\
\hline 2 & H-D-Ala-Phe-Lys-EACA-OH & 49 & 21.5 & 477.6 & 478.5 \\
\hline 3 & H-Ala-Phe-Lys-EACA-OH & 47 & 21.5 & 477.6 & 478.4 \\
\hline 4 & H-D-Ala-Phe-EACA-OH & 56 & 17.8 & 349.4 & 350.5 \\
\hline 5 & H-Ala-Phe-EACA-OH & 54 & 17.6 & 349.4 & 350.7 \\
\hline 6 & H-Phe-Lys-EACA-NH ${ }_{2}$ & 51 & 19.3 & 405.5 & 406.3 \\
\hline 7 & H-D-Ala-Phe-Lys-EACA- $\mathrm{NH}_{2}$ & 48 & 23.6 & 476.6 & 477.4 \\
\hline 8 & $\mathrm{H}-\mathrm{Ala}-\mathrm{Phe}-\mathrm{Lys}-\mathrm{EACA}-\mathrm{NH}_{2}$ & 50 & 23.9 & 476.6 & 477.8 \\
\hline 9 & $\mathrm{H}-\mathrm{D}-\mathrm{Ala}-\mathrm{Phe}-\mathrm{EACA}-\mathrm{NH}_{2}$ & 55 & 18.9 & 348.4 & 349.3 \\
\hline 10 & $\mathrm{H}-\mathrm{Ala}-\mathrm{Phe}-\mathrm{EACA}-\mathrm{NH}_{2}$ & 49 & 18.6 & 348.4 & 349.3 \\
\hline 11 & $\mathrm{H}-\mathrm{Phe}-\mathrm{Lys}-\mathrm{EACA}-\mathrm{NH}-\left(\mathrm{CH}_{2}\right)_{5}-\mathrm{NH}_{2}$ & 42 & 16.9 & 490.7 & 491.2 \\
\hline 12 & H-D-Ala-Phe-Lys-EACA-NH- $\left(\mathrm{CH}_{2}\right)_{5}-\mathrm{NH}_{2}$ & 38 & 18.5 & 561.8 & 562.4 \\
\hline 13 & $\mathrm{H}-\mathrm{Ala}-\mathrm{Phe}-\mathrm{Lys}-\mathrm{EACA}-\mathrm{NH}-\left(\mathrm{CH}_{2}\right)_{5}-\mathrm{NH}_{2}$ & 37 & 18.7 & 561.8 & 562.5 \\
\hline 14 & $\mathrm{H}-\mathrm{D}-\mathrm{Ala}-\mathrm{Phe}-\mathrm{EACA}-\mathrm{NH}-\left(\mathrm{CH}_{2}\right)_{5}-\mathrm{NH}_{2}$ & 43 & 16.8 & 433.6 & 434.5 \\
\hline 15 & $\mathrm{H}-\mathrm{Ala}-\mathrm{Phe}-\mathrm{EACA}-\mathrm{NH}-\left(\mathrm{CH}_{2}\right)_{5}-\mathrm{NH}_{2}$ & 41 & 15.9 & 433.6 & 434.1 \\
\hline
\end{tabular}

Daltonics Esquire 6000 (Bruker Daltonik GmbH, Leipzig, Germany) with electrospray ionization (ESI).

\section{Enzymatic Investigations}

Determination of amidolytic activity was performed as previously described by (Okada et al. 1988). Buffer and $0.1 \mathrm{ml}$ of enzyme solution was added to $0.2 \mathrm{ml}$ of examined compound dissolved in $0.15 \mathrm{M} \mathrm{NaCl}$ (1-15) (as control $0.15 \mathrm{M} \mathrm{NaCl}$ ). The buffer and the enzyme solution included:

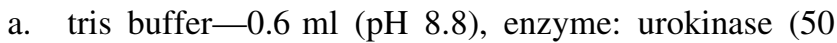
units/ml), synthetic substrate: S-2444 $(0.1 \mathrm{ml}, 3 \mathrm{mM})$;

b. tris buffer- $0.5 \mathrm{ml}(\mathrm{pH}$ 8.4), enzyme: thrombin (1 units $/ \mathrm{ml})$, synthetic substrate: S-2238 $(0.2 \mathrm{ml}$, $0.75 \mathrm{mM}$ );

c. tris buffer $-0.5 \mathrm{ml}$ ( $\mathrm{pH} 7.4)$, enzyme: plasmin $(0.4$ units/ml), synthetic substrate: S-2251 $(0.2 \mathrm{ml}, 3 \mathrm{mM})$;

d. borane buffer- $0.5 \mathrm{ml}(\mathrm{pH} 7.5)$, enzyme: trypsin $(0.4$ units/ml), synthetic substrate: Bzl-L-Arg-pNA.HCl $(0.2 \mathrm{ml}, 8 \mathrm{mM})$;

e. tris buffer- $0.6 \mathrm{ml}$ ( $\mathrm{pH}$ 9.0), enzyme: kallikrein (3 units $/ \mathrm{ml})$, synthetic substrate: S-2266 $(0.1 \mathrm{ml}$, $75 \mathrm{mM}$ );

f. tris buffer-0.6 $\mathrm{ml}(\mathrm{pH} 8.4)$, enzyme: t-PA (167 mg/ $\mathrm{ml})$, synthetic substrate: $\mathrm{S}-2288(0.1 \mathrm{ml}, 10 \mathrm{mM})$.

The results are given in Table $2 . \mathrm{IC}_{50}$ values were determined $\left(\mathrm{IC}_{50}\right.$, Inhibitor Concentration, the concentration at which enzyme activity is inhibited by $50 \%$ ). Our results were compared with the 6-aminohexanoic acid. No effect was observed in maximum concentration $(20 \mathrm{mM})$ for EACA of all tested enzymes.

\section{Antyfibrinolytic Activity}

\section{Study Subject}

Five healthy volunteers, men (age range: $25-34$ years)) with normal blood cell counts were entered into the study. Healthy volunteers had not taken medication known to affect platelet function and/or coagulation for at least 10 days before blood sampling. Study protocol was approved by the Ethics Committee at the Medical University of Bialystok (No R-I-002/224/2015). The procedures were in accordance with the Declaration of Helsinki of 1975, as revised in 2000 and blood samples were obtained with the subjects' informed consent.

\section{Blood Collection}

Venous blood was collected with minimum trauma and stasis via a 21 -gauge needle $(0.8 \times 40 \mathrm{~mm})$ into $9 \mathrm{ml}$ polypropylene vacuum tubes (Vacuette, Greiner Bio-One, Kremsmünster, Austria) containing $130 \mathrm{mM}$ trisodium citrate. Blood was stored at room temperature for $30 \mathrm{~min}$ after venipuncture and then was evaluated by thromboelastometric analyses.

\section{Thromboelastometric (ROTEM) Analyses}

ROTEM technology is described elsewhere (Luddington 2005). Thromboelastometric measurements were performed using ROTEM system (Tem International $\mathrm{GmbH}$, Manheim, Germany). Recalcified $(10 \mathrm{mM} \mathrm{CaCl} 2)$ blood was assessed for fibrinolytic potential using either $140 \mathrm{ng} /$ $\mathrm{ml}$ tissue factor (TF), and $125 \mathrm{ng} / \mathrm{ml}$ tissue PLG activator 
Table 2 Inhibition of synthesized tripeptides on the amidolytic activity of enzymes

\begin{tabular}{|c|c|c|c|c|c|c|}
\hline \multirow[t]{2}{*}{ No } & \multirow[t]{2}{*}{ Compound } & \multicolumn{5}{|l|}{$\mathrm{IC}_{50}(\mathrm{mM})$} \\
\hline & & Plasmin & Thrombin & tPA & uPA & Trypsin \\
\hline 1 & H-Phe-Lys-EACA-OH & $11.39 \pm 0.91$ & - & - & - & $15.44 \pm 1.24$ \\
\hline 2 & H-D-Ala-Phe-Lys-EACA-OH & $3.37 \pm 0.27$ & $3.85 \pm 0.31$ & $14.40 \pm 1.15$ & - & - \\
\hline 3 & H-Ala-Phe-Lys-EACA-OH & $4.82 \pm 0.39$ & $5.04 \pm 0.40$ & $17.64 \pm 1.41$ & - & - \\
\hline 4 & H-D-Ala-Phe-EACA-OH & $10.89 \pm 0.87$ & - & $6.48 \pm 0.52$ & $3.17 \pm 0.25$ & - \\
\hline 5 & H-Ala-Phe-EACA-OH & - & $4.77 \pm 0.38$ & - & $3.38 \pm 0.27$ & - \\
\hline 6 & H-Phe-Lys-EACA- $\mathrm{NH}_{2}$ & $1.43 \pm 0.11$ & - & - & - & - \\
\hline 7 & H-D-Ala-Phe-Lys-EACA- $\mathrm{NH}_{2}$ & $0.02 \pm 0.0016$ & - & - & - & - \\
\hline 8 & H-Ala-Phe-Lys-EACA-NH ${ }_{2}$ & $0.13 \pm 0.01$ & $7.59 \pm 0.61$ & - & - & - \\
\hline 9 & H-D-Ala-Phe-EACA-NH ${ }_{2}$ & $1.55 \pm 0.12$ & - & - & - & - \\
\hline 10 & $\mathrm{H}-\mathrm{Ala}-\mathrm{Phe}-\mathrm{EACA}-\mathrm{NH}_{2}$ & - & - & - & $2.61 \pm 0.21$ & - \\
\hline 11 & H-Phe-Lys-EACA-NH- $\left(\mathrm{CH}_{2}\right)_{5}-\mathrm{NH}_{2}$ & $4.82 \pm 0.39$ & - & - & - & - \\
\hline 12 & H-D-Ala-Phe-Lys-EACA-NH- $\left(\mathrm{CH}_{2}\right)_{5}-\mathrm{NH}_{2}$ & $1.11 \pm 0.09$ & - & - & - & - \\
\hline 13 & $\mathrm{H}-\mathrm{Ala}-\mathrm{Phe}-\mathrm{Lys}-\mathrm{EACA}-\mathrm{NH}-\left(\mathrm{CH}_{2}\right)_{5}-\mathrm{NH}_{2}$ & $1.4 \pm 0.11$ & - & - & - & - \\
\hline 14 & H-D-Ala-Phe-EACA-NH- $\left(\mathrm{CH}_{2}\right)_{5}-\mathrm{NH}_{2}$ & $4.77 \pm 0.38$ & - & - & - & - \\
\hline 15 & $\mathrm{H}-\mathrm{Ala}-\mathrm{Phe}-\mathrm{EACA}-\mathrm{NH}-\left(\mathrm{CH}_{2}\right)_{5}-\mathrm{NH}_{2}$ & - & - & - & - & - \\
\hline
\end{tabular}

$(-)=$ No cytotoxic effect was observed in maximum concentration $(20 \mathrm{mM})$. The examined compounds did not influence the enzymatic activity of kallikrein in maximum concentration $(20 \mathrm{mM})$

(tPA). We measured the parameters characterized kinetic of clot formation (clotting time, alpha angle), clot strength (maximal clot firmness; MCF), and fibrinolysis (percentage reduction of $\mathrm{MCF}$, clot lysis time). All ROTEM measurements were performed by the same experienced operator as follows: $0.32 \mathrm{ml}$ of blood (previously treated/preincubated with tested substances) was transferred into a preheated cup containing $20 \mu \mathrm{l}$ of re-calcification reagents and repeatedly gently pipetted to mix the components (Rusak et al. 2014) (Fig. 3; Table 3).

\section{Antitumor Activity}

\section{Tissue Culture}

All studies were performed on MCF-7, MDA-MB-231 and DLD cells lines were purchased from American Type Culture Collection (Rockville, MD). The cells were maintained in DMEM supplemented with $5 \%$ fetal bovine serum (FBS), $2 \mathrm{mmol} / \mathrm{ml}$ glutamine, $50 \mathrm{U} / \mathrm{ml}$ penicillin, $50 \mathrm{mg} / \mathrm{ml}$ streptomycin at $37{ }^{\circ} \mathrm{C}$ in a $5 \% \mathrm{CO}_{2}$ incubator.

\section{Cytotoxicity Assay}

The toxicity of the evaluated peptides was determined by the method of Plumb et al. (1989) in 10, 100, 250, 500 and $1000 \mu \mathrm{M}$ concentrations. MCF-7, MDA-MB-231 and DLD cells were maintained as described above. The detailed description of the method is given by (Markowska et al. 2013).

\section{Results and Discussion}

For all the peptides antiamidolytic activity was evaluated against six enzymes from the group of serine proteasesplasmin, thrombin, tPA, uPA, kallikrein and trypsin. The thromboelastometric test was performed to examine the effect of the synthesised compounds on coagulation and fibrinolysis in whole blood. Additionally, the influence of peptides on the viability of fibroblast cells, colon carcinoma line DLD-1 and breast carcinoma cell lines MCF-7 and MDA-MB-231 was examined.

Out of the 15 peptides obtained, 12 inhibited the activity of plasmin with $\mathrm{IC}_{50}$ values ranging from 0.02 to $11.39 \mathrm{mM}$. Four compounds exhibited $\mathrm{IC}_{50}$ values towards thrombin ranging from 3.85 to $7.59 \mathrm{mM}$. TPA was inhibited by 3 of the synthesised compounds with $\mathrm{IC}_{50}$ values from 6.48 to $17.64 \mathrm{mM}$ and 3 of them inhibited urokinase with $\mathrm{IC}_{50}$ values from 2.61 to $3.38 \mathrm{mM}$ (Table. 2). The use of the characteristic -Ala-Phe-Lys- sequence of plasmin inhibition resulted in obtaining eight peptides selective for plasmin.

In the case of peptides with a free carboxyl group, peptide H-D-Ala-Phe-Lys-EACA-OH 2 showed the highest inhibition of plasmin activity with $\mathrm{IC}_{50} 3.37 \mathrm{mM}$. Peptide 2 exibited the highest activity against thrombin 


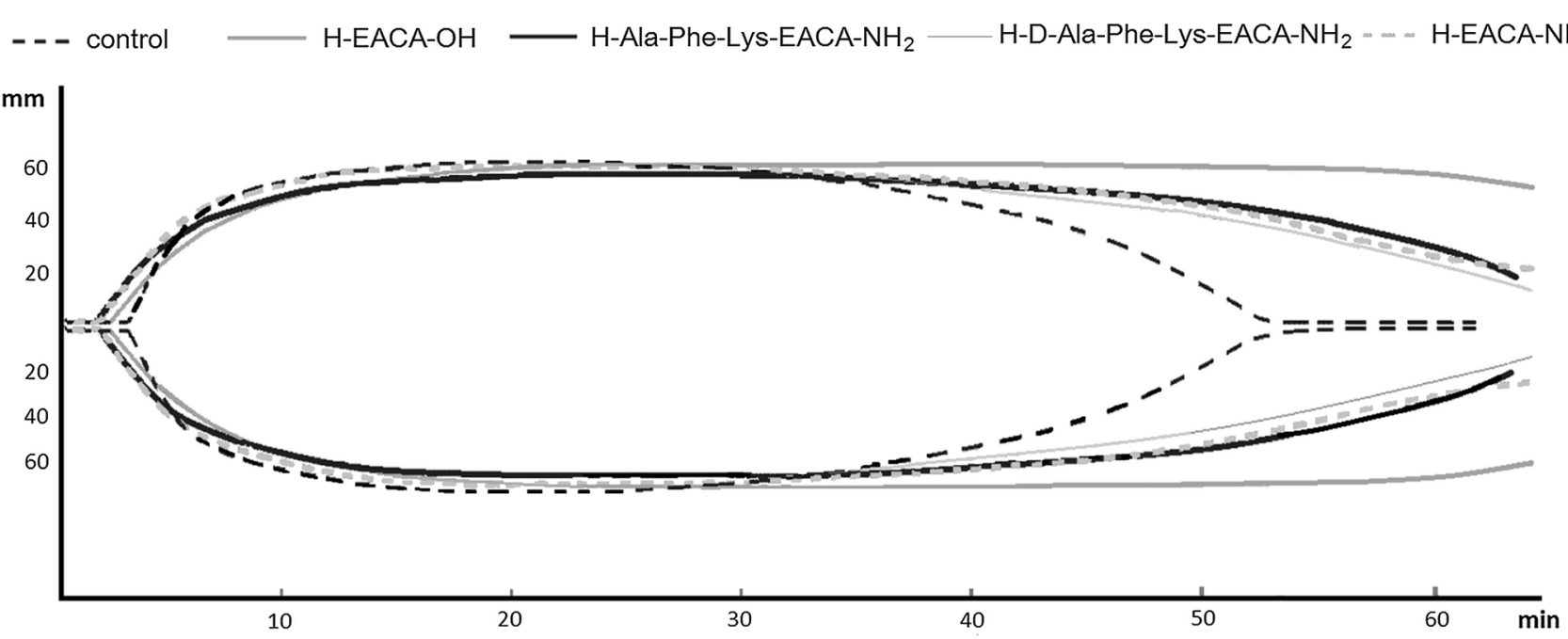

Fig. 3 Typical thromboelastometric tracing obtained for analyzed compounds control: blood without additives. The results of one representative experiment (out of eight) are presented

Table 3 Effect of analyzed compounds on fibrinolysis parametersthromboelastometric data

\begin{tabular}{|c|c|c|c|}
\hline Compounds & LOT (s) & LT (min) & LI30-LI45-LI60 (\%) \\
\hline Control & $1993 \pm 111$ & $48 \pm 4$ & $91-39-2$ \\
\hline $\mathrm{H}-\mathrm{EACA}-\mathrm{OH}$ & $\geq 4084$ & $\geq 168$ & $100-98-92$ \\
\hline $\mathrm{H}-\mathrm{EACA}-\mathrm{NH}_{2}$ & $2488 \pm 172$ & $71 \pm 5$ & $96-80-32$ \\
\hline H-Ala-Phe-Lys-EACA-NH ${ }_{2}$ & $2731 \pm 160$ & $76 \pm 6$ & $99-86-43$ \\
\hline $\mathrm{H}-\mathrm{D}-\mathrm{Ala}-\mathrm{Phe}-\mathrm{Lys}-\mathrm{EACA}-\mathrm{NH}_{2}$ & $2519 \pm 176$ & $72 \pm 4$ & $97-79-28$ \\
\hline
\end{tabular}

LOT lysis onset time- time from the start of coagulation to the point which the amplitude of formed clot is reduced by $15 \%$ (s). LT lysis time, when clot is reduced/lysed by $90 \%$ (s). LI30-LI45-LI60 Lysis index amplitude of clot (\%) after 30, 45, 60 min (\%). Control without synthesized peptides with $\mathrm{IC}_{50}$ values of $3.85 \mathrm{mM}$. It was observed that the removal of lysine from the sequence resulted in a complete loss of activity only in the case of peptide H-Ala-PheEACA-OH 5 containing L-alanine whereas in the case of peptide 4 with alanine in the $\mathrm{D}$ configuration, the activity was merely reduced with the $\mathrm{IC}_{50}$ value of $10.89 \mathrm{mM}$.

The highest inhibition of plasmin activity was exhibited by the amide of peptide $\mathrm{H}-\mathrm{D}-\mathrm{Ala}-\mathrm{Phe}-\mathrm{Lys}-\mathrm{EACA}-\mathrm{NH}_{2} \mathbf{7}$, which also proved to be the most active compound of all the synthesised compounds of the 1-15 series. Peptides HPhe-Lys-EACA-NH ${ }_{2}$ 6, H-Ala-Phe-Lys-EACA-NH 28 and $\mathrm{H}-\mathrm{D}-\mathrm{Ala}-\mathrm{Phe}-\mathrm{EACA}-\mathrm{NH}_{2} \mathbf{9}$ inhibited plasmin activity with $\mathrm{IC}_{50}$ values of $1.43 \mathrm{mM}, 0.13 \mathrm{mM}$, and $1.55 \mathrm{mM}$ respectively. It was also observed that in this group the removal of lysine from the sequence resulted in a complete loss of activity only in the case of peptide $\mathbf{1 0}$ containing Lalanine.

Another series of compounds were peptides with secondary amides with the 1,5-diaminopentyl moieties (fragment of the natural diamine-cadaverine). MiduraNowaczek et al. 1990 proposed the insertion of plasmin 1,5-diaminopentyl residue as a form of decarboxylated lysine-cadaverine into the structures of peptide inhibitors. Use of this fragment was based on thrombin inhibitors containing the decarboxylated structure-agmatine in the place of the C-terminal arginine (Rewinkel and Adang 1999). A previously synthesised amide derivative of lysine (Ac-Lys-NH- $\left(\mathrm{CH}_{2}\right)_{5}-\mathrm{NH}_{2}$ ) inhibited plasmin activity with $\mathrm{IC}_{50}$ values of $8 \mathrm{mM}$ (Midura-Nowaczek et al. 2008). In contrast, a peptide with a similar sequence to the analysed H-Ala-Phe-Lys-NH- $\left(\mathrm{CH}_{2}\right)_{5}$ $\mathrm{NH}_{2}$ showed no plasmin inhibitory activity (MiduraNowaczek et al. 1990). The most active inhibitor of plasmin activity in the described cadaverine series was peptide $\mathrm{H}-\mathrm{D}-\mathrm{Ala}-\mathrm{Phe}-\mathrm{Lys}-\mathrm{EACA}-\mathrm{NH}-\left(\mathrm{CH}_{2}\right)_{5} \mathrm{NH}_{2} \quad \mathbf{1 2}$ with $\mathrm{IC}_{50} 1.11 \mathrm{mM}$. The removal of lysine from the sequence resulted in H-Ala-Phe-EACA-NH- $\left(\mathrm{CH}_{2}\right)_{5} \mathrm{NH}_{2}$ $\mathbf{1 5}$ not inhibiting plasmin.

We describe five different peptide sequences in this paper. In our tests the inhibitors containing the $N$-terminal D-Ala proved marginally more active than those containing L-Ala. $\mathrm{IC}_{50}$ values were in the range of $0.02 \mathrm{mM} 7$ to $3.37 \mathrm{mM} 2$ for peptides with D-Ala and from $0.13 \mathrm{mM} 8$ to $4.82 \mathrm{mM} 3$ in the case of L-Ala. 
We also compared the activity of some of the peptides synthesised with the literature data regarding similar peptides containing EACA (-Ala-Phe-Lys- vs. -Ala-PheLys-EACA-). Compounds with a free carboxyl group of H-D-Ala-Phe-Lys-EACA-OH 2 and H-Ala-Phe-LysEACA-OH 3 exerted an enhanced plasmin inhibitory activity effect compared to the corresponding $\mathrm{H}-\mathrm{D}-\mathrm{Ala}-$ Phe-Lys-OH and H-Ala-Phe-Lys-OH. The $\mathrm{IC}_{50}$ values of the analysed compounds containing D-alanine or L-alanine were lower in comparison with the values of the compounds previously synthesised by Markowska et al. (2007).

Replacement of the lysine on EACA in parent sequence (-Ala-Phe-Lys- vs. -Ala-Phe-EACA-) resulted in growth inhibition towards plasmin. In the case of amides of peptides H-D-Ala-Phe-EACA- $\mathrm{NH}_{2} 9$ and H-D-Ala-PheEACA-NH- $\left(\mathrm{CH}_{2}\right)_{5}-\mathrm{NH}_{2} \quad 14$ a significant increase of inhibition was observed $\left(\mathrm{IC}_{50}=1.55 \mathrm{mM}\right.$ for $\mathbf{9}$, $\mathrm{IC}_{50}=4.77 \mathrm{mM}$ for $\mathbf{1 4}$, no activity for H-D-Ala-PheLys- $\mathrm{NH}_{2}$ (Markowska et al. (2007)) and for H-D-Ala-PheLys-NH- $\left(\mathrm{CH}_{2}\right)_{5}-\mathrm{NH}_{2}$ (Midura-Nowaczek et al. 1990).

Amides of the synthesised peptide H-D-Ala-Phe-LysEACA-NH $\mathrm{NH}_{2} \quad \mathbf{7}$ and $\mathrm{H}-\mathrm{Ala}-\mathrm{Phe}-\mathrm{Lys}-\mathrm{EACA}-\mathrm{NH}_{2} \quad \mathbf{8}$ exhibited a significant inhibitory effect on plasmin activity $\left(\mathrm{IC}_{50}=0.02 \mathrm{mM}\right.$ and $\left.\mathrm{IC}_{50}=0.13 \mathrm{mM}\right)$ while compounds with $C$-terminal lysine $\mathrm{H}-\mathrm{D}-\mathrm{Ala}-\mathrm{Phe}-\mathrm{Lys}-\mathrm{NH}_{2}$ and $\mathrm{H}-$ Ala-Phe-Lys- $\mathrm{NH}_{2}$ completely lacked this effect (MiduraNowaczek et al. 2003).

In the case of cadverine derivatives of the synthesised compounds it was possible to compare only the compound $\mathrm{H}-\mathrm{Phe}-\mathrm{Lys}-\mathrm{EACA}-\mathrm{NH}-\left(\mathrm{CH}_{2}\right)_{5}-\mathrm{NH}_{2} \quad \mathbf{1 1}$ with unpublished data regarding the compound $\mathrm{H}-\mathrm{Phe}-\mathrm{Lys}-\mathrm{NH}-$ $\left(\mathrm{CH}_{2}\right)_{5}-\mathrm{NH}_{2}$ available at the Department of Organic Chemistry of Bialystok Medical University. Peptide 11 with $\mathrm{IC}_{50}=4.82 \mathrm{mM}$ proved significantly more active than the corresponding compound without EACA.

Due to the antifibrinolytic effect of $\varepsilon$-aminocaproic acid, the tromboelastometric test was conducted to investigate the effect exerted by the peptides on the kinetics of clot formation and stability in human blood.

The selected compounds did not influence coagulation parameters in the thromboelastometric assay. Only in the case of H-D-Ala-Phe-Lys-EACA-NH 7115 s (1.9 min.) and $\mathrm{H}-\mathrm{Ala}-\mathrm{Phe}-\mathrm{Lys}-\mathrm{EACA}-\mathrm{NH}_{2} 8135 \mathrm{~s}$ (2.25 min.), a marginal reduction in the control clotting time (CT-coagulation time) $174 \mathrm{~s}$ (2.9 min.) was observed. EACA and its amide demonstrated a similar effect (137 and $117 \mathrm{~s}$ respectively). It did not have any impact on the activation of prothrombin exhibited by the absence of a significant change in the $\alpha$ angle $\left(68-73^{\circ}\right.$ to control $\left.75^{\circ}\right)$.

In all cases a clot was formed with similar consistency as evidenced by the unchanged value of maximal clot firmness (MCF) (56-59 relative to control 60). It was observed that in the presence of the synthesised compounds fibrinolysis of the formed clot occurred more slowly (LIlyse index, expressed in \%). Comparing the value of lysis in $45 \mathrm{~min}\left(\mathrm{LI}_{45}\right)$ the whole blood lysis is about $61 \%$ of the clot. In the presence of $\mathrm{H}-\mathrm{EACA}-\mathrm{OH}$ fibrinolysis was almost completely inhibited $(1 \%)$ while in the presence of H-EACA-NH $H_{2}(20 \%)$, H-Ala-Phe-Lys-EACA-NH 28 (14\%) and the H-D-Ala-Phe-Lys-EACA-NH 7 (21\%) it was reduced.

The time at which the clot decreased by $15 \%$ (parameter LOT-lysis onset time) and $90 \%$ (parameter LT-lysis time) was also examined. In the case of the synthesised compounds an increase in LOT relative to the control was observed. The clot decreased by $15 \%$ after approximately $45 \mathrm{~min}$ (2731 s) and $90 \%$ after about $67 \mathrm{~min}$ (4060 s) in the case of H-Ala-Phe-Lys-EACA$\mathrm{NH}_{2} \mathbf{8}$, while in the presence of tPA in pure blood fibrinolysis was at the level of $15 \%$ after approximately $33 \mathrm{~min}$ (1993 s), and $90 \%$ after about $48 \mathrm{~min}$ (2912 s). A similar effect was observed for the EACA amide and $\mathrm{H}-$ D-Ala-Phe-Lys-EACA-NH $\mathrm{NH}_{2}$ 7. In the case of EACA these parameters were not determined due to its antifibrinolytic activity.

In conclusion, the synthesised peptides produced a less marked antifibrinolytic effect compared with EACA, but the effect was more profound in comparison with the control. The most probable reason for a reduction in this activity is the inhibition of peptide interaction with LBS of plasmin/PLG achieved by blocking the amino group in EACA through amide bond with tripeptide -Ala-Phe-Lysand blocking the carboxyl group as an amide.

Owing to the established anti-tumor properties of the Ala-Phe-Lys- sequence present in the synthesised peptides, impact of peptides on healthy cells-fibroblasts, and cancerous cells - colon carcinoma cell lines DLD-1 breast cancer cells MCF-7 and MDA-MB -231 was also examined.

The peptide -Ala-Phe-Lys- was inserted into the structure of prodrugs recognised by plasmin to selectively strengthen their anti-tumor activity and to reduce side effects of the potential therapeutic agent. Plasmin, whose large quantities occur in cancer cells (and other components of the PLG activation system), recognises the sequence -Ala-Phe-Lys and releases the active drug through a hydrolysis reaction. The prodrugs of doxorubicin(Takemura and Fujiwara 2007), camptothecin (De Groot et al. 2002), paclitaxel (De Groot et al. 2000), daunorubicin (De Groot et al. 1999) and methotrexate (Warnecke et al. 2007) proposed by various authors have displayed increased cytotoxicity against cancer cell line MCF-7, EVSA-T, WIDR IGROV, M19, A498, and H226 in cell assays.

The described peptides did not exert any cytotoxic effects on normal cells and cancer cells. Referring to the 
mechanism of action of de Groot's prodrugs it is not possible to observe bond hydrolysis in the described inhibitors between EACA and lysine due to the fact that plasmin is an endopeptidase and does not hydrolyse the $C$-terminal amino acids of peptides or proteins (McDonald 1985). In fact, in contrast to the hydrolysis of synthetic substrates used in the enzymatic experiments, mass spectrometry confirmed that there was no hydrolysis of EACA of the peptides fragments. Therefore, it is impossible to suggest a mechanism of action of the described inhibitors similar to that of de Groot's anticancer prodrugs. The mechanism of action of peptides presented in the paper is based on direct interaction with the active site and "lysine binding sites" in plasmin. Nevertheless, the presence of C-terminal EACA may be responsible for reduced cytotoxicity to the tested cells.

The reported findings are the result of basic research and require further testing.

\section{Conclusion}

Peptide derivatives of plasmin inhibitors containing the EACA and (-Ala-Phe-Lys-) with biological antiamidolytic and antifibrynolytic activity were synthesised. The peptide $\mathrm{H}-\mathrm{D}-\mathrm{Ala}-\mathrm{Phe}-\mathrm{Lys}-\mathrm{EACA}-\mathrm{NH}_{2} \mathbf{8}$ was found to be a selective inhibitor of plasmin compared to other examined serine proteases. The highest fibrinolytic activity was displayed by $\mathrm{H}-\mathrm{D}-\mathrm{Ala}-\mathrm{Phe}-\mathrm{Lys}-\mathrm{EACA}-\mathrm{NH}_{2}$ 8 and $\mathrm{H}-\mathrm{Ala}-\mathrm{Phe}-\mathrm{Lys}-\mathrm{EACA}-\mathrm{NH}_{2}$ 7. Nevertheless, it was less profound than the fibrinolytic activity of EACA, which may be due to dimension misalignment and lack of interactions between the anionic and cationic centres in the lysine-binding sites. Despite the presence of the sequence -Ala-Phe-Lys accepted to be responsible for the enhanced antitumor properties of known prodrugs, no cytotoxicity against either fibroblasts or cancer cell line (colon carcinoma line DLD-1 and breast carcinoma lines MCF-7 and MDA-MB-231) was observed. This may suggest that the presence of C-terminal EACA, which did not display cytotoxicity in our tests, in the synthesised peptides may be responsible for increasing the viability of the tested cells.

\section{Compliance with Ethical Standards}

Conflict of Interest The paper was developed using the equipment purchased within the The Operational Programme Development of Eastern Poland 2007-2013 The authors declare no conflict of interest.

Open Access This article is distributed under the terms of the Creative Commons Attribution 4.0 International License (http://crea tivecommons.org/licenses/by/4.0/), which permits unrestricted use, distribution, and reproduction in any medium, provided you give appropriate credit to the original author(s) and the source, provide a link to the Creative Commons license, and indicate if changes were made.

\section{References}

Al-Horani RA, Desai UR (2014) Recent advances on plasmin inhibitors for the treatment of fibrinolysis-related disorders. Med Res Rev 34(6):1168-1216

Angliker H, Wikstrom P, Rauber P, Shaw E (1988) Synthesis and properties of peptidyl derivatives of arginylfluoromethanes. Biochem J 256:481-486

Backes BJ, Harris JL, Leonetti F, Craik CS, Ellman JA (2000) Synthesis of positional-scanning libraries of fluorogenic peptide substrates to define the extended substrate specificity of plasmin and thrombin. Nat Biotech 18:187-193

Bajusz S, Szell E, Barabas E, Bagdy D (1981) Structure-activity relationship among the tripeptide aldehyde inhibitors of plasmin and thrombin In: Rich DH, Gross E (eds) Peptides: SynthesisStructure-Function Proceeding of the Seventh American Peptide Symposium Pierce Chem Co, Rockford Illinois, pp. 417-420

Berg DA, Menino AR (1992) Bovine embryos produce a urokinasetype plasminogen activator. Mol Reprod Dev 31:14-19

Bhavanis V, Vikram B, Subbro M, Bikram D (2013) Role of tranexamic acid in reducing postoperative blood loss and transfusion requirement in patients undergoing hip and femoral surgeries. Saudi J Anaesth 7(1):29-32

Bruzgo I, Midura-Nowaczek K, Bruzgo M, Kaczyńska J, Roszkowska-Jakimiec W (2006) Effect of $\varepsilon$-aminocaproylamino acids on fibrin formation. Acta Pol Pharm Drug Res 63(2):149-152

Carmeliet P, Collen D (1995) Gene targeting and gene transfer studies of the biological role of the plasminogen/plasmin system. Thromb Haemost 74(1):429-436

Carroll VA, Binder BR (1999) The role of the plasminogen activation system in cancer. Semin Thromb Hemost 25:183-197

Castellino FJ, Ploplis VA (2005) Structure and function of the plasminogen/plasmin system. Thromb Haemost 93(4):647-654

Chan WC, White PD (2000) Fmoc solid phase peptide synthesis. Oxford University Press, New York

Choi WS, Irwin MG, Samman N (2009) The effect of tranexamic acid on blood loss during orthoganic surgery, a randomized controlled trial. J Maxillofac Surg 76:125-133

Cockell CS, Marshall JM, Dawson KM, Cederholm-Williams SA, Ponting CP (1998) Evidence that the conformation of unliganded human plasminogen is maintained via an intramolecular interaction between the lysine-binding site of kringle 5 and the N-terminal peptide. Biochem J 333(1):99-105

Collen D, Lijnen HR (1991) Basic and clinical aspects of fibrinolysis and thrombolysis. Blood 8:3114-3124

Collen D, Lijen HR, De Cock F, Durieux JP, Loffet A (1980) Kinetic properties of tripeptide lysyl chloromethyl ketone and lysyl p-nitroanilide derivatives towards trypsin-like serine proteinases. Biochim Biophys Acta 615:158-166

De Groot FMH, De Bart ACW, Verheijen JH, Scheeren HW (1999) Synthesis and biological evaluation of novel prodrugs of anthracyclines for selective activation by the tumor-associated protease plasmin. J Med Chem 42:5277-5283

De Groot FMH, Van Berkom LWA, Scheeren HW (2000) Synthesis and biological evaluation of $2^{\prime}$-carbamate-linked and $2^{\prime}$-carbonate-linked prodrugs of paclitaxel: selective activation by the tumor-associated protease plasmin. J Med Chem 43:30933102 
De Groot FMH, Busscher GF, Aben RW, Scheeren HW (2002) Novel 20-carbonate linked prodrugs of camptothecin and 9-aminocamptothecin designed for activation by tumour-associated plasmin. Bioorg Med Chem Lett 12(17):2371-2376

Fareed J, Messmore HL, Kindel G, Balis JU (1981) Inhibition of serine proteases by low molecular weight peptides and their derivatives. Ann NY Acad Sci 370:765-784

Friberger P, Knös M, Gustavsson S, Aurell L, Claeson G (1982) A new specific substrate for the determination of plasmin activity. Scand J Clin Lab Invest 42(suppl 162):121-127

Fuji A, Tanaka K, Cook ES (1972) Antistaphylococcal and antifibrinolytic activities of $\mathrm{N} \alpha-(\omega$-aminoacyl-)-L-lysines. J Med Chem $15: 378-380$

Ganu VS, Shaw E (1987) Improved synthetic inactivators of plasmin. Thromb Res 45:1-6

George SJ, Johnson JL, Smith MA, Jackson CL (2001) Plasminmediated fibroblast growth factor-2 mobilisation supports smooth muscle cell proliferation in human saphenous vein. J Vasc Res 38(5):492-501

Hancock WS, Battersby JE (1976) A new micro-test for the detection of incomplete coupling reactions in solid-phase peptide synthesis using 2,4,6-trinitrobenzenesulphonic acid. Anal Biochem 71:260-264

Hochschwender SM, Laursen RA (1981) The lysine binding sites of human plasminogen. J Biol Chem 256:11172-11176

Huarte J, Vassalli JD, Belin D, Sakkas D (1993) Involvement of the plasminogen activator/plasmin proteolytic cascade in fertilization. Dev Biol 157:539-546

Kahar PN, Gupta N, Govil P, Shab V (2009) Efficacy and safety of tranexamic acid in control of bleeding following TKR a randomized clinical trial. Indian J Anaesth 53:667-671

Kucharewicz I, Kowal K, Buczko W, Bodzenta-Lukaszyk A (2003) The plasmin system in airway remodeling. Thromb Res 112(1-2): $1-7$

Kwaan HC, McMahon B (2009) The role of plasminogen-plasmin system in cancer. Cancer Treat Res 148:43-66

Lerch PG, Rickli EE, Lergier W, Gillessen D (1980) Localization of individual lysine-binding regions in human plasminogen and investigation on their complex-forming properties. Eur $\mathbf{J}$ Biochem 107:7-13

Lucas MA, Fretto LJ, McKee PA (1983) The binding of human plasminogen to fibrin and fibrinogen. $J$ Biol Chem 258:4249-4256

Luddington R (2005) Thrombelastography/thromboelastometry. Clin Lab Haematol 27:81-90

Maeda S, Nakajima K, Tohyama Y, Kohsaka S (2009) Characteristic response of astrocytes to plasminogen/plasmin to upregulate transforming growth factor beta 3 (TGFbeta3) production/ secretion through proteinase-activated receptor-1 (PAR-1) and the downstream phosphatidylinositol 3-kinase (PI3 K)-Akt/PKB signaling cascade. Brain Res 1305:1-13

Markowska A, Bruzgo I, Midura-Nowaczek K (2006) Methylketone inhibitors of plasmin. Pharmazie 61:898-900

Markowska A, Midura-Nowaczek K, Bruzgo I (2007) Low molecular peptides as potential inhibitors of plasmin. Acta Pol Pharm Drug Res 64(4):355-358

Markowska A, Bruzgo M, Surażyński A, Midura-Nowaczek K (2013) Tripeptides with non-code amino acids as potential serine proteases inhibitors. J Enzyme Inhibit Med Chem 28(1-6):639-643

McDonald JK (1985) An overview of protease specificity and catalytic mechanisms: aspects related to nomenclature and classification. Histochem J 17:773-785

Midura-Nowaczek K, Bruzgo I, Roszkowska-Jakimiec W, Worowski K (1990) Peptide inhibitors of plasmin. Acta Pol Pharm Drug Res 47(1):39-42
Midura-Nowaczek K, Bruzgo I, Roszkowska-Jakimiec W, Worowski K (1994) Synthesis and activity of dipeptides containing epsilon-aminocaproic acid. Acta Pol Pharm Drug Res 51(6):499-504

Midura-Nowaczek K, Bruzgo I, Roszkowska-Jakimiec W, Worowski K (1996) Synthesis and activity of N epsilon-aminocaproyl-Lnorleucine derivatives. Acta Pol Pharm Drug Res 53(3):221-223

Midura-Nowaczek K, Roszkowska-Jakimiec W, Lepietuszko I, Bruzgo I (2003) Synthesis peptide inhibitors of plasmin. Pharmazie 10:687-689

Midura-Nowaczek K, Lepietuszko I, Bruzgo I (2006) Synthesis of alkylamides of dipeptides as potential plasmin inhibitors. Acta Pol Pharm Drug Res 63(1):33-37

Midura-Nowaczek K, Lepietuszko I, Bruzgo I, Markowska A (2008) Biological activity of amide derivatives of lysine. Acta Pol Pharm Drug Res 65(3):377-381

Moroi M, Aoki N (1976) Isolation and characterization of alpha2plasmin inhibitor from human plasma a novel proteinase inhibitor which inhibits activator-induced clot lysis. J Biol Chem 251(19):5956-5965

Muramatu M, Fuji S (1971) Inhibitory effects of $\omega$-amino acid esters on trypsin plasmin, plasma kallikrein and thrombin. Biochim Biophys Acta 242:203-208

Nagamatsu A, Okuma T, Watanabe M, Yamamura Y (1963) The inhibition of plasmin by some amino acid derivatives. J Biochem 54:491-496

Okada Y, Tsuda Y, Teno N, Wanaka K, Boghaki M, HijitakaOkunomija A, Naito T, Okamoto S (1988) Synthesis of active center-directed peptide inhibitors of plasmin. Chem Pharm Bull 36:1289-1297

Ortmann MW, Basser MW, Klein AA (2013) Antifibrinolytic agents in current anaesthetic practice. $\mathrm{Br} \mathrm{J}$ Anaesth 111(4): 459-463

Pepper MS, Montesano R, Mandriota SJ, Orc L, Vassalli JD (1996) Angiogenesis: a paradigm for balanced extracellular proteolysis during cell migration and morphogenesis. Enz Prot 49:138-162

Plumb JA, Milroy R, Kaye SB (1989) Effects of the pH dependence of 3-(4,5-dimethylthiazol-2-yl)-2,5-diphenyltetrazolium bromide-formazan absorption on chemosensitivity determined by a novel tetrazolium-based assay. Cancer Res 49:4435-4440

Purwin M, Bruzgo I, Markowska A, Midura-Nowaczek K (2009) Short peptides containing L-lysine and $\varepsilon$-aminocaproic acid as potential plasmin inhibitors. Pharmazie 64:765-767

Rewinkel JBM, Adang AEP (1999) Strategies and progress towards the ideal orally active thrombin inhibitor. Curr Pharm Des 5:1043-1075

Robbins KC, Summaria L, Hsieh B, Shah RJ (1967) The peptide chains of human plasmin Mechanism of activation of human plasminogen to plasmin. J Biol Chem 242(10):2333-2342

Rusak T, Piszcz J, Misztal T, Brańska-Januszewska J, Tomasiak M (2014) Platelet-related fibrinolysis resistance in patients suffering from PV Impact of clot retraction and isovolemic erythrocytapheresis. Thromb Res 134(1):192-198

Sappino AP, Huarte J, Belin D, Vassalli JD (1989) Plasminogen activators in tissue remodeling and invasion: mRNA localization in mouse ovaries and implanting embryos. $\mathrm{J}$ Cell Biol 109:2471-2479

Shanmukhappa K, Matte U, Degen JL, Bezerra JA (2009) Plasminmediated proteolysis is required for hepatocyte growth factor activation during liver repair. J Biol Chem 284(19): $12917-12923$

Takemura G, Fujiwara H (2007) Doxorubicin-induced cardiomyopathy from the cardiotoxic mechanisms to management. Prog Cardiovasc Dis 49:330-352 
Vassalli JD, Sappino AP, Belin D (1991) The plasminogen activator/plasmin system. J Clin Invest 88:1067-1072

Vojkovski T (1995) Detection of secondary amines on solid phase. Pept Res 8:236-237

Warnecke A, Fichtner I, Saß G, Kratz F (2007) Synthesis, cleavage profile, and antitumor efficacy of an albumin-binding prodrug of methotrexate that is cleaved by plasmin and cathepsin. B Arch Pharm 340(8):389-395

Westlund LE, Lunden R, Wallen P (1982) Effect of EACA, PAMBA, AMCHA and AMBOCA on fibrinolysis induced by streptokinase, urokinase and tissue activator. Haemost 11(4):235-241 